\title{
Sustainability of Islamic Micro Finance Institutions (IMFIs)
}

\author{
Siti Khadijah. A. $M^{1, *}$, N. E. P. Saleh ${ }^{2}$, M. F. Kamarudin ${ }^{3}$, Haryadi ${ }^{4}$ \\ ${ }^{1}$ Accounting Research Institute (ARI) \& Academy of Contemporary Islamic Studies (ACIS), Universiti Teknologi MARA, 40450, \\ Malaysia \\ ${ }^{2}$ Faculty of Business, Universiti Selangor, 40000, Malaysia \\ ${ }^{3}$ Faculty of Business Management, Universiti Teknologi MARA, 40450, Malaysia \\ ${ }^{4}$ Takaful Mikro Indonesia (TAKMIN), Bogor, 16310, Indonesia \\ *Corresponding Author: sitik274@salam.uitm.edu.my
}

Copyright (C) 2013 Horizon Research Publishing All rights reserved.

\begin{abstract}
Islamic micro finance was introduced as an option for the low-income people to get funds in order for them to uplift their well-being and to get themselves out of the poverty. Nevertheless, the borrowers face unwarranted event such as illness, death, fire or theft that may cause improbable setbacks which in turn lead to non-performance of financing. These probable risks will certainly affect the sustainability of the micro finance institutions thus defeating the very reason of its establishment. In this respect, the implementation of risk mitigating instrument via micro Takaful to under privilege group is an interesting issue to ponder. This study explores the implementation of micro Takaful as a way of mitigating the potential risk among micro finance borrowers. A series of interviews was conducted with the practitioners of the respective institutions in the selected sample country (Indonesia) to get a closer look at the practice. Finding of the study indicates that micro Takaful helps a lot in sustaining Islamic micro finance institutions in the country. Nevertheless, this new trend is still lacking of empirical research, more so when we talk about its offering in the market. Hence, further research in this area is necessary and very much recommended.
\end{abstract}

Keywords Micro Insurance, Micro Takaful, Sustainability, Islamic Micro Finance (IMF)

\section{Introduction}

Islam as a system that differs fundamentally from the prevailing conventional systems has its Maqasid al-Shariah (goals of shariah) to be attained through the practice and implementation of shariah. This is important to realize falah or success of man's life in this world and the world hereafter. These Maqasid or goals are the safeguarding of our al-daruriyyah al-khams (essential needs) comprising hifz al-deen (the safeguarding of faith), hifz al-nafs (the safeguarding of life), hifz al-aql (the safeguarding of intellect), hifz al-nasb (the safeguarding of progeny) and hifz al-mal (the safeguarding of wealth) $[1-4]$. The safeguarding of faith is the utmost ingredient of shariah as faith puts human being to behave on a proper foundation (the straight path or sirat al-mustaqim). It also provides moral filter [1] for the utilization, allocation and distribution of resources thereby the goals of Islamic financial system to have a broad-based economic well being with full employment and optimum rate of economic growth, to attain socio-economic justice and equitable distribution of income and wealth, to have stability in the value of money, to have mobilization and investment of savings for economic development in an equitable manner, and to have effective rendering of services normally expected from the banking system [5] can be materialized. In the context of business conduct, this manifestation of faith may become a powerful mitigating system against all sorts of misconducts or moral hazards in contractual business relationship.

In Islamic economic system, a highly skewed inequality of income and wealth among the societies is incompatible to shariah. This could happen when wealth is concentrated in the hands of the few. Hence, emphasis is given on equitable distribution of income and wealth so as to minimize the gap between the rich and the poor. In doing so, every individual should be given equal opportunity in enhancing their quality of life. In other words, equal accessibility on financial services should be given among all individuals in the society. One of the ways is through the introduction of micro insurance (or micro Takaful in Islamic context) as a risk mitigating tool for Islamic micro finance (IMF).

Micro insurance is an instrument whereby financial arrangement is made to protect low income people against risks in exchange for premium payment [6,7]. Proportionate premium is paid to cover common types of risks such as life, health, disability and property (especially crops in agricultural insurance). Studies showed that micro insurance is a good alternative of risk mitigation instrument for 
low-income people [7]. Having micro insurance, low income people could cover their health, death, their children's education, their housing loan, agricultural risks and other services equivalent to those served for upper income people. Studies on poverty indicate that the deprivation of the poor from getting access to financial services is the main obstacle to poverty alleviation as they could not be able to take advantage of economic opportunities, build assets and pay for their children's education. High risk of default has been identified as among the main reason for inaccessibility of the poor to get finance. In this regard, micro insurance has an important role in mitigating the risk and hence sustaining micro finance instrument [8].

In the precarious world of the poor, unwarranted event such as illness, death, fire or theft can cause improbable setbacks. Commonly, crises such as the death of a breadwinner or the hospitalization of a family member will not only move families to a lower economic level, but also leave them without the tools to recover from poverty in the absence of significant assets and other risk mitigation mechanisms, the poor lack the capacity to withstand the consequences of many shocks. As such, micro insurance serve as a means for the poor to manage their risk. It is a type of formal insurance mechanism that protects low-income people against specific perils. Like all insurance, micro insurance policy holders pay regular premium payments proportionate to the likelihood and cost of the risk involved [9]. Micro insurance is specifically designed for the protection of low-income people, with affordable insurance products to help them cope with and recover from common risks [10].

Previous studies indicate that micro insurance is a good alternative of risk mitigation instrument for borrowers of micro finance. This is proven as study [8] by Rossel on poverty outreach of and indicates that there is positive effect of micro insurance on the breadth of micro finance outreach thereby sustaining micro finance institutions.

Micro insurance is specifically designed for the protection of low-income people, with affordable insurance products to help them cope with and recover from common risks [10]. Previous studies indicate that micro insurance is a good alternative of risk mitigation instrument for low-income borrower. Micro insurance could cover health, death, education, housing, agricultural risks and as such. It should also lead to exploration of the use of micro insurance as a safety net mechanism to reduce the economic vulnerability of low-income populations [10].

Micro insurance is a relatively new intervention to address the vulnerability of the poor. The term micro insurance has only been around since the late 1990s. Since its emergence, micro insurance has received significant attention [7]. At the global level, micro insurance network is known as the Consultative Group to Assist the Poor (CGAP), an informal grouping of organizations and individuals committed to the development of micro insurance.

In India micro insurance has already increased the voice of the excluded groups and is beginning to influence the policy and legal context that governs social protection. This country currently has the most dynamic micro insurance sector in the world [7]. A few Asian countries are pioneering the development of micro insurance and have shown promising results. In Southeast Asia today, particularly in the microfinance industry of Cambodia, the Philippines and Vietnam, micro insurance has become an integral component of poverty reduction, being able to provide cost effective protection to the poor [11]. Micro insurance complements the MFIs' because it reduces their vulnerability to business, personal risks [12]. They have interest in delivering micro insurance due to cross-selling considerations in improving efficiency and tapping new sources of income, and because insurance reduces the financial risk for the borrower and the lender [13]. Micro insurance can help poor people better manage risk and avoid falling back down the poverty ladder when faced with shocks.

A study on best practice micro insurance by CGAP on a selected 25 case study samples had produced six fundamentals of best practice micro insurance [6]. The six fundamentals are market needs, product design, premiums, process, distribution and market education.

Market needs: Low-income households in emerging economies have different insurance needs than the relatively affluent households in developed countries. Therefore, scaled down versions of traditional insurance products cannot be sold as micro insurance. Micro insurance products should be tailored to the target customer group, and should be easily understandable by these target customers $[6,13]$.

Product design: To keep premiums affordable, only major risks should be covered with a relatively small benefit package such as personal accident, credit life, group life, extended warranty and multi-peril $[6,14]$. Policy language should be simple. There should only be a few exclusions, if any. To reduce administrative costs and the risk of adverse selection, group insurance policies are preferred [13]. Premiums: Premium amounts and payment schedules should fit to clients' cash-flows; ideally, premiums are tied to existing cash-flows like loan payments. Such an approach reduces premium collection costs to a minimum. Group pricing helps to keep the underwriting process simple [13, 14].

Processes: Policy application requirements and claims documentation should be reduced to a minimum; claims should be settled quickly $[6,15]$.

Distribution: To keep distribution cost low, micro insurance is usually distributed by partner organizations which already have an established relationship with potential customers like microcredit institutions [15].

Market education: In most developing countries, people are neither familiar with specific insurance products nor with the general mechanism of insurance. However, a market for insurance products can only function if potential insurance customers understand the basic mechanism and trust insurance companies to pay in the event of a claim. Therefore, educating potential customers as well as insurers' sales agents and staff about the insurance mechanism is 
important for future market growth $[14,16]$.

This study would explore the implementation of Islamic micro insurance (or micro Takaful) as a way of mitigating the potential risk among micro finance borrowers. An emphasis is given to the actual practice of Islamic Micro Finance (IMF) and Islamic Micro Takaful (IMT), rather than that of the conventional counterparts, as the former conform to the maqasid (objectives) of shariah (Islamic laws). Among ASEAN countries, the implementation of such concept in Indonesia is chosen as sample of the study. A series of unstructured interviews was conducted with the practitioners of the respective institutions in the country to get in-depth details of the practice.

\section{Materials and Methods}

This study is qualitative in nature. In order to gather the required information on the actual practice of micro insurance and micro finance in Indonesia, a series of face-to-face interviews was conducted with the practitioners of the respective institutions in the country. All the information were written in notes and recorded on tape during the interviews. This is important to preserve the preciseness of the data, apart from preventing biasness in the case of error in recalling from memory. The people which have been interviewed were The Syariah Advisor of PT Haura Arzuda Media, The Managing Director of PT Asuransi Takaful Keluarga, Head of Marketing Division of PT Asuransi Takaful Keluarga, Head of Strategy \& Research Marketing Department of PT Asuransi Takaful Keluarga, Head of Micro Insurance Department of PT Asuransi Takaful Keluarga, Head of Claim Non Health Department of PT Asuransi Takaful Keluarga, The Managing Director of Takaful Mikro Indonesia, The Admin \& Customer Relation of Takaful Mikro Indonesia, The Program Director of Takaful Mikro Indonesia, The President Director of Bank Syariah Insan Cita and The Head of Grameen-Model IMF/Rector of Tazkia University College of Islamic Economics.

Relevant printed documents were also scrutinized to get further details on the practice. In addition, a site visit to a group of IMF recipients in a remote village of Cijayanti in Babakan Madang, Bogor was conducted to get the real picture of IMF practice.

\section{Result and Discussion}

As the largest Muslim country in the world, Indonesia has a complex microfinance and rural finance sector which has evolved over more than a century. Nevertheless, the implementation of IMF had only started quite recently after the emergence of Islamic finance in 1991. There are three types of IMF in Indonesia generally. The first is the Islamic Rural Bank which is well known in Indonesia as Bank Pembiayaan Rakyat Syariah (BPRS). The second is Koperasi Baytul Maal wat Tamwil (KBMT) and the third is
Gramen-Model IMF. These institutions are contracted with micro Takaful provider via an agent known as Takaful Mikro Indonesia. These subsections explored each institution and their roles in providing benefits to the low-income earners particularly IMF borrowers.

Bank Pembiayaan Rakyat Syariah (BPRS): Bank Pembiayaan Rakyat Syariah (BPRS) is governed by the Central Bank of Indonesia under Law No. 10, 1998. It operates under the same effective prudential regulation and supervision as commercial banks and conventional rural banks (BPR). After a promising start in the early 1990s, their development has since almost come to a standstill. Anyhow, BPRS focus on the micro sector instead of starting with more profitable market segments such as salary earners and small entrepreneurs. It is this difference in mission which has contributed to the slow growth of BPRS. While both BPR and BPRS are (mostly) established by wealthy local people, the owners of BPR are commercially oriented towards increasing their wealth, while the owners of BPRS have a social mission, combined with the intention to at least cover their costs.

Most BPRS are privately owned, usually by one majority shareholder and several minority shareholders. In some cases, Islamic foundations, companies and local government are shareholders. Most owners are absentee owners, living in Jakarta or one of the provincial capitals. If there are many shareholders, their involvement in decision-making is small if not absent. In contrast, many owners of conventional BPR also act as general managers or president-directors.

Every BPRS has three boards: a sharia board that monitor the compliance if it's operation with Islamic principles, a management board and a supervisory board. Members of the sharia board usually come from religious organizations like the local Majlis Ulama, from mass organizations and Islamic universities. The supervisory board of commissioners (komisaris) comprises representatives of majority shareholders and financial experts. There are usually three members on the sharia board and three on the supervisory board. It is rare that any member has a regular full-time or part-time position; most act perhaps one day a month or upon request. The management board usually comprises a director and a deputy director, who are both full-time employees.

Upon the insistence of Bank Indonesia as the regulator, management is usually comprised of one or two directors with banking experience. As Islamic banking is relatively new in Indonesian financial market and given that the country is facing shortage of trained bankers, very few BPRS managers have any experience in sharia banking. Most are retirees from conventional banking, who have received only some training in Islamic banking principles. This has resulted in a selection of older people, frequently from state banks, who perhaps lack the drive and innovativeness that one might expect from younger people that eager to experiment with new ideas in Islamic banking. Management is largely autonomous, sometimes indeed too much so, particularly in the case of absentee owners combined with management by retired state bankers experienced in 
enforcing bureaucratic rules rather than exploring new products and customer segments. No evidence was found of any conflict of interest between management, board and shareholders. This could be due to the way the decision-making is done i.e. consensus (musyawarah). As mentioned earlier, lack of management skill and dynamics are considered the only major problems.

In governing the institution, internal control is done by absentee commissioners whose activities are limited to receiving monthly reports and monthly or quarterly visits by way of the commissioners visit the bank or the bank visits the commissioners even in faraway places. Their role is generally considered not very effective - hence the considerable autonomy of management. As far as external governing is concerned, external auditing by a public accountant is compulsory if the assets exceed IDR 10 billion. Nevertheless, many of the institutions are lacking of dynamic growth and remain below that limit. ASBISINDO, the business association of Islamic banks, recommends voluntary external auditing. However, past experience showed that it more is problematic compared to the existing method. Supervision of BPRS as part of the banking system is compulsory and carried out by Bank Indonesia on an annual basis. Accounting and reporting standards, including the computation of standard performance ratios, are regulated and enforced by Bank Indonesia.

Most BPRS have a system performance incentive scheme based on an annual bonus which is related to the bank's profit, rather than to the performance of individual staff members. There is an ongoing discussion on how to adjust staff remuneration to the profit-sharing principle of Islamic banking, with a basic salary to cover transportation and an advance, plus a sharing of the profit between owners and staff according to an agreed-upon ratio. BPRS Mentari in Garut is experimenting along these lines.

In the national banking system, BPRS is the bank which was established to provide business for micro and small enterprises (MSEs). Shariah Islamic principles enforced in the BPRS are built for financing transactions (savings and deposits) and financing (loans). BPRS manages its public funds by using profit sharing system (mudharabah). By sharing system, public depositors will get the results that highly dependent on fluctuation of BPRS' income. Any savings or deposits in the BPRS will receive assurances from Lembaga Penjamin Simpanan (LPS), so that people will feel safe to keep their funds in the BPRS.

The BPRS market segment covers the enterprising poor with existing enterprises, predominantly small traders. BPRS are open to all, irrespective of their religion. Under sharia banking, there are two models of client selection: (i) clients with existing businesses and successful operations for at least two years, and (ii) new entrepreneurs without previous business experience. The vast majority of clients fall into the first category, with an existing business and a good track record; they can be financed through such financial products as Murabahah, Musyarakah and Mudarabah, which involve some form of profit-sharing. New clients without a track record are considered very risky and represent a small minority of the total clients funded; they can be financed through Qard Hasan, soft loans without any charge or profit-sharing.

In a financing transaction (loan), BPRS provides financing to SMEs either with a purchase system (murabahah), profit and loss sharing (musyarakah) or lease (ijarah). The choice of the Islamic system is dependent upon the type of financing proposed by the society to the BPRS. In addition, the BPRS can also practice Islamic pawnshop (ar-rahn) run by the Islamic system.

Even though the size of all BPRS is small, their performance should not be underestimated. That is shown by the level of deposits in Sharia Rural Banks. The rate of deposits per month in the BPRS can reach about 15 to 16 percent. This figure was much higher than the percentage amount by conventional banks.

Many advantages possessed by the BPRS if compared to the commercial banks, especially in the customers or borrowers approach. BPRS approach was very personal and close to the borrowers. The simple procedures were applied, for example when customers want to make loan or financing, they do not need to fulfill the complicated requirement. Therefore, it will build up good relations and trust between banks and debtors.

Koperasi Baytul Maal wat Tamwil (KBMT): Secondly is the Koperasi Baytul Maal wat Tamwil (KBMT) which is a savings and credit cooperative implementing a profit and loss sharing approach. The first of its kind was established in 1994. KBMT's target is to promote the poor in the community to involve in business with a hope that in future it can alleviate their standard of living. In other words, the mission is to help the enterprising poor in the vicinity and to empower them economically. Their particular target market is very small micro-entrepreneurs including itinerant traders and food vendors. KBMT actually evolved from the initial stage as Baytul Maal wat Tamwil (BMT) (pre-cooperatives or saving-and-lending institutions without a legal base), and it is an independent organizations recognized by the law as cooperatives. Having a legal status allows them to avail of limited support from government programs.

The BMT is a variant of the Islamic microfinance system. It is a community-based microfinance institutions that operate under the cooperative system and NGO domain. Structurally, it encompasses Baitul Tamwil and Baitul Maal. The Baitul Tamwil is designed to conduct financial intermediations through mobilizing deposits from member clients and financing commercial ventures. In addition, the Baitul Maal is dedicated to perform socio-religious roles by collecting charity donations from Muslims and helping the needy along with their spiritual lives. In other words, BMT is composed of two words, namely Baitul Mal (BM) which means the treasury house and Baitul Tamwil (BT), which means financing house. The treasury house is a place to collect and distribute the benevolence funds, while the financing house is a place that works to mobilize public funds to have rotated in the form of financing for business 
development. Thus, BMT can be defined as a group or institution of community organizations that raise funds from members, for both savings and zakat (alms giving) for distribution in the form of commercial and non commercial financing as an effort to strengthen and empower the people who are economically weak or marginal.

The root of BMT was developed in decade of 1980 by Muslim activists. Later on, the BMT has flourished since in the mid of 1990s, after the establishment of Bank Muamalat Indonesia, the first Syariah bank in the country. The latest available information reveals that there are about 3000 BMTs across the country, serving nearly 2 million savers and 1.5 million borrowers. In general, the BMT institutions have been initiated and led by leading Islamic organizations, Syariah banks, Islamic boarding schools (pesantren), respected clerics and Muslims patrons who have strong socio-economic and religious influences in the community.

As cooperatives, they are owned by their members. As a member in the organizations, they are given the highest power in the Annual Members Meeting, which they can elect the Board of Directors and the Management. Board size and composition of BMT are not standardized. Internal control is generally in the hands of a supervisory board, which either meets monthly or on an ad hoc basis. Examples of BMT that exist in Indonesia were BMT Wihdatul Ummah, BMT Khidamatul Ummah, BMT Tadbiirul Ummah, BMT Nahdhatul Ummah and many others. BMT Wihdatul Ummah is a cooperative that collects funds in the form of zakat (alms giving), infak (donation), charity and savings to be channeled for micro-enterprises. The small traders were often difficulty in obtaining capital, especially if they make the loan to the bank.

The rapid development of BMT in Indonesia is not followed by the development of reporting regulations and accounting standards. The precise definite legal status of BMT is somehow in doubt and here is no accounting standard specially made for BMT. The role of BMT in microfinance institution is not small. The number of BMT has risen from 300 at the end of 1995, to 1501 at the end of 1997, and to 2470 in 1998 [17]. BMT suffer from the same regulatory and supervisory neglect as the rest of the sector. After a period of rapid growth during much of the 1990s, they are now in decline, with perhaps no more than one-fifth in good health. Fresh money pumped into the sector without effective regulation and supervision will contribute to their downfall, as has been the case in the state-supported cooperative sector.

At the outset, the BMT initiative had strong political support. More recently, however, the BMT sector has attracted less government interest. The evidence show that there is only a small number of BMT were registered by the regulatory body therefore it is quite difficult to present the whole picture and position of this sector in the broader microfinance landscape. Lately ample critics have been raised by public toward governance practices, modus operandi, products and services that are perceived to be too much like the secular programs, rather than Shariah compliant, as well as to several BMT that are more favor on profits and rent-seeking behaviors instead to promote its socio-religious objectives. In addition, there are many BMT, including those established under the government's programs, have become insolvent and bankrupt due to lack of support and proper supervision from the authorized agency.

Regardless these drawbacks, pros and cons, the above discussions clearly show that BMT model would be an excellent approach to alleviate the multi-dimensional poverty in the Muslim societies. There are a lot of advantages for the government using these community-based financiers as the driver for anti poverty and wealth distribution among the inhabitants, more importantly is to anticipate the gloomy prospect and the severe impact of economic crisis. The feasible suggestion is the government should embrace the BMT sector in the economic stimulus package that just approved by the parliament. The presence of BMT can be embedded in the financial access to micro, small and medium enterprises program particularly by involving as many as viable BMT institutions into the credit guarantee scheme and linkage programs to strengthen their financing capacity and outreach. For the long run perspective, the government should pay more attention on the existence of BMT by providing clear regulation and supervision, technical assistance etc as like as its counterpart the conventional microfinance sector.

Grameen Model IMF: Grameen Bank, a unique financial institution, was established with the aims to help the poor and has replaced physical collateral requirements with group responsibility. It had shown the possibility to develop a viable and self-reliant credit program for the poor. The Grameen 'model' has been copied in more than 40 countries; it is the most widely cited development success story in the world; and its charismatic Founder-Director, Professor Muhammad Yunus, was awarded with the Nobel Peace Prize in 2006. By the end of February 2008 it had 7.4 million clients and an outstanding loan of $\$ 545$ million. By any measure it is an organization that has impacted greatly on the lives of many poor people and on ideas about microfinance, poverty reduction and international development. Grameen Bank approach also proves that financial intermediation is a viable device to fight poverty, and an excellent vehicle for community development $[18,19,20]$. Since then, micro-finance program have been part of the poverty alleviation policies and strategies. It became a popular approach, especially to reach the poor who would normally be excluded from the formal credit sector [21].

The loan and the accrued interest are repayable in small weekly installments over a period of one year. The bank also provides comprehensive investment advice to its clients and helps them to generate savings for themselves. The loan-collection rate of the Grameen Bank is nearly $98 \%$, a rate that is far higher than that of any other conventional financial institution operating in the country [19]. The most distinctive feature of the Grameen Bank is that $95 \%$ of its borrowers are women. The bank provides loans to poor 
people who are unable to provide collateral and indoctrinated in Grameen social values, known as the sixteen decisions [22]. Grameen borrowers also vow to observe the bank's four basic principles, and they are the owners of the bank.

By organizing poor people into groups, it has created the social and financial conditions enabling them to receive loans; it has demonstrated that the poor are bankable, capable of making good business decisions in utilizing their loans and repaying them on time [18]. Two elements are shared by the most effective antipoverty programs: community participation needs to be disaggregated by social groups, especially women, rather than being based on territory and microenterprise programs can effectively support existing and new businesses with credit and technical assistance [20].

Results from dynamic fixed-effects probit model demonstrate that individual repayments outcomes are significantly influenced by own lagged repayment behavior and by averages of lagged repayment behaviors for the remaining members of a group. Simulations of own and cross effects between participants provide further support for strong inter-dependencies at the group level in repayment outcomes. By strengthening mutual support networks, such inter-dependencies may be crucial for poverty alleviation in developing countries such as Bangladesh [23]. On top of that, Grameen Bank's successful lies on specialized delivery system, emphasizing direct targeting, informality of delivery, and delivering credit to the "doorsteps" of the poor [21].

Grameen Bank transforms its participants from a passive recipient of credit to a well responsive and active agent in economic and non-economic aspects of life. This transformation sets up an encouraging context for the effective public policies for economic and social changes at a reduced transaction cost [24].

Grameen Bank replication program in Indonesia was started in Bogor, West Java by Karya Usaha Mandiri (KUM) in 1989. This initiative was followed in 1993 by Mitra Karya East Java (MKEJ) in Malang, East Java. In Sumatra, Grameen Bank model was replicated by Yayasan Pokmas Mandiri (YPM) [25]. In 2003, Mitra Bisnis Keluarga (MBK or Family Business Partners) was established which aims to provide working capital to low-income women in Java, Indonesia, in order to provide them access to formal financial services, reduce their vulnerably, and raise their standard of living. Since then, MBK has now become the largest Grameen replication microfinance institution in Indonesia. The MIX Global 100 ranks MBK Ventura from Indonesia as the top performing MFI in 2009 for the second year in a row, in large part due to the MFI's highly efficient operations [26]. In line with strong demand for Islamic micro finance from the under privilege group UPK Ikhtiar, the first Islamic Grameen replication microfinance institution in Indonesia, was established. In Indonesia, the Grameen Bank replicators fall under the purview of Ministry of Finance or Ministry of Cooperative. The classification between these two ministries is based on nature of the establishment of Grameen Bank replicators.

As seen in other countries the Grameen Bank replicators in Indonesia is operated unsubsidized. In fulfilling the needs for safekeeping among the low-income group they offer micro savings services as well as pension funds. It will be collected on the weekly basis. If the depositors wish to withdraw they have to borrow from the pool and make payment subsequently. On the financing side, the Grameen Banks replicators offer microcredit to the targeted group. In the precarious world of the poor, unwarranted event such as illness, death, fire or theft can cause improbable setbacks. Commonly, crises such as the death of a breadwinner or the hospitalization of a family member will not only move families to a lower economic level, but also leave them without the tools to recover from poverty in the absence of significant assets and other risk mitigation mechanisms, the poor lack the capacity to withstand the consequences of many shocks. As such, financing extended to low-income group is covered by micro insurance products offer by Grameen Banks replicators. Interestingly, the burgeoning of Islamic micro finance has given birth to micro takaful in Indonesia.

The Grameen Bank replicators in Indonesia are also targeting the poor women which organize into group. The formation these groups have created the social and financial conditions enabling them to receive loans. Simulations of own and cross effects between participants provide further support for strong inter-dependencies at the group level in repayment outcomes.

In addition, Islamic Grameen replicators have inculcated the Islamic values among the low income group by organizing recitation of Al-Quran and fardhu ain classes. Such mutual support and renewed understanding of religion of Islam have given positive impact for poverty alleviation in Indonesia. Meanwhile, it was seen the respected figure in the society also plays significant role in implementing the Grameen Banks Model. On top of that, the Grameen Banks replicators in Indonesia are blessing with dedicated staffs that ensure impartial delivery of services to the poor. Moreover, the advancement in technology does enhance the efficiency as well as reducing the operation costs for Grameen Banks replicators.

Micro Takaful and IMFIs: The preceding discussion had elaborated on the existing micro finance institutions that offer Islamic method of financing. In this regard, Indonesia had been pioneering the implementation of micro insurance concept in its micro finance market as a way to mitigate the financial risk of the loan. More interestingly is the fact that the country introduced the Islamic way of providing micro insurance (known as micro Takaful Sakinah-later termed as MT Sakinah) to be attached to its IMF programmes. MT Sakinah is a specifically designed Takaful product under Asuransi Takaful Keluarga (ATK) Indonesia. Having been launched in 2005, the product is offered to IMF borrowers under Islamic credit life insurance on the basis of Wakalah (agency). The participants of MT (also known as nasabah) are required to pay certain sum of tabarru' (philanthropic contribution) as a form of premium (in conventional term) to cover any potential risk of death or total disability among the 
fellow participants.

Tabarru' generally is the agreement by a participant to relinquish a sum of contribution as donation that a person pays into a Takaful Fund. The purpose of this donation is to provide mutual indemnity to the Takaful participants. The donation acts as a mutual help and joint guarantee should any fellow participants suffer a defined loss such as death.

The term participant (nasabah) is used in Islamic micro insurance as the borrowers are considered participating in the collective coverage of MT. Each participant is expected to contribute certain sum of money with the intention of helping other fellow participants in the event of loss. Other participants will in return help the initial contributor with coverage on loss that inflicted him or her. In short, the scheme allows the participants to help one another in case of difficulty. Indeed, the implementation of MT enables the participants to be ready with contingency plan in facing potential loss in the future. This particular concept would not only give a peace of mind to them but more importantly provide them with higher credit-worthiness hence greater accessibility to IMT.

In Indonesian practice, participation in MT Sakinah is made compulsory in order for the low-income people to get IMF funding from the above-mentioned IMF institutions. Nevertheless, as the main owner of the instrument, ATK Indonesia did not manage the operation of MT Sakinah by itself. Rather, the management is delegated to an appointed agency institution known as TAKMIN [27].

TAKMIN, an acronym for Takaful Mikro Indonesia was set up by an appointed working group under Yayasan Pramu Bogor in October 2005. The main function of TAKMIN is to act as representative of PT-ATK Indonesia in selling and servicing micro insurance product to members of MFIs (known as nasabah Lembaga Kewangan Mikro Syariah or LKMS) that have contracted with TAKMIN. In specific, TAKMIN functions in: (i) making a selection and screening the potential participants with the cooperation of MT institution, (ii) planning for a more suitable product to the low income earners, (iii) linking MT institution with MFIs in giving the best treatment to participants, (iv) help to increase the capacity of MFIs via micro Takaful and (v) educating the public on the essence of micro Takaful.

The existence of TAKMIN as agent that link MT institution and MFIs had benefited all the respective parties. The MT institutions could now get access to the low-income earners which were previously inaccessible to them. The MFIs could be able to serve their micro finance products at a lower risk and more importantly, the poor people could now enjoy the benefit of insurance coverage which they could hardly get before. This is indeed a win-win-win situation to all.

The performance of TAKMIN is commendable and promising owing to the fact that the premium paid by the participants is increasing consistently from year to year. It was reported that the collected premiums had increased consistently from as small as USD346 in the year 2007 up to USD1,295 in 2010. Indeed, the number of MFIs had also increased from 13 in 2007 to 44 in 2010 [27]. TAKMIN function as a mediating partner between the provider of insurance and the insured had facilitated a lot in ensuring the longevity and sustainability of the service. Their close presence and their effectiveness in managing and operating the service to the customers had prompted other potential customers to participate in Takaful. In addition, the Indonesian geography that covers vast area had made close presence of the agent a convenience to the people, hence promising potentials in the future.

\section{Conclusion}

This paper gave an overview of micro Takaful practice and how the propagation of micro Takaful is significant towards sustainability of micro finance institutions by providing cover for unwarranted events such as such as illness, death, fire or theft can cause improbable setbacks which in turn lead to non-performance of financing thus wobble the sustainability of micro finance institutions. Commonly, crises such as the death of a breadwinner or the hospitalization of a family member will not only move families to a lower economic level, but also leave them without the tools to recover from poverty. In the absence of significant assets and other risk mitigation mechanisms, the poor lack the capacity to withstand the consequences of shocks. While micro insurance had been in existence for more than a decade, micro Takaful is still considered new in the field of Islamic finance. It was indicated that this new trend is still lacking of empirical research, more so when we talk about its offering in the market. Hence, further research in this area is necessary and very much recommended.

Acknowledgements

We are very grateful to those who have contributed directly or indirectly in this research paper.

\section{REFERENCES}

[1] Chapra, M. U. Islam and the Economic Challenge. United Kingdom: The Islamic Foundation and the International Institute of Islamic Thought, 1992.

[2] Al-Omar, Fuad \& Abdel Haq, Mohamed. Islamic banking: Theory, practice and challenges. Karachi: Oxford University Press, 1996.

[3] Mohd Daud Bakar. To what extent have Islamic banking practices realized the Maqasid al-Shariah. Paper presented at IIUM International Conference on Islamic Banking and Finance, Kuala Lumpur, 2007.

[4] Abdulazeem Abozaid \& Asyraf Wajdi Dusuki. The challenges of realizing Maqasid al-Shari'ah in Islamic Banking and Finance. Paper presented at IIUM International Conference on Islamic Banking and Finance, Organized by IIUM Institute of Islamic Banking and Finance, 23-25th April, Kuala Lumpur, 2007. 
[5] Chapra, M. U. Towards a Just Monetary System. Leicester, UK: The Islamic Foundation, 1985.

[6] Churchill, C. What is Insurance for the Poor? In C. Churchill (Ed.), 2006.

[7] Churchill, C. Insuring the Low-Income Market: Challenges and Solutions for Commercial Insurers. The Geneva Papers 32 401-412, 2007.

[8] Rossel-Cambier, K. Do Multiple Financial Services Enhance the Poverty Outreach of Microfinance Institutions? Working Paper. Université Libre de Bruxelles - Solvay Brussels School of Economics and Management Centre Emile Bernheim, ULA, 2010.

[9] Cohen, M., M. J. M. a. J. S. Reducing Vulnerability: Demand for and Supply of Microinsurance in East Africa. Journal of International Development 17: 319-325, 2005.

[10] Allianz AG, GTZ \& UNDP. Microinsurance Demand and Market Prospects Indonesia, 2006.

[11] Jaime Aristotle B. Alip, and Takayoshi Amenomori. Formalizing grassroots social security: the experience of CARD in the Philippines. In Grassroots Social Security in Asia: Mutual Aid, Micro Insurance and Social Welfare (eds). New York, USA; Routledge, 2011.

[12] Barbin, E. A., Lomboy C \& Soriano, E. S. A field study of micro insurance in the Philippines. Working Paper, International Labour Office (ILO) Geneva, 2002.

[13] Wohlner, E. Providing Insurance of Real Value to the Poor, Micro insurance in Focus Note, No. 12, 2008.

[14] Wipf, J., D. Liber and C. Churchill. Product Design and Insurance Risk Management, in C. Churchill (Ed.), Protecting the Poor. A Micro insurance Compendium (pp. 146-173). Geneva: International Labour Office, 2006.

[15] Dercon, S., T. Bold and C. Calvo. Insurance for the Poor? (University of Oxford QEH Working Paper No. 125), 2004.

[16] CGAP Working Group on Micro insurance. Recommendations for Commercial Insurers, Micro insurance in Focus Note, No. 7, 2008.

[17] Timberg, TA. Islamic Banking in Indonesia, Proceedings of BRI International Seminar on Micro banking System, December, 1999.

[18] Hassan, M. K. and L. Renteria-Guerrero. The experience of the Grameen Bank of Bangladesh in community development. International Journal of Social Economics 24(12): 1488 1523, 1997.

[19] Wahid, A. The Grameen Bank and women in Bangladesh. Challenge 42(5): 94-101, 1999.

[20] Tinker, I. Alleviating poverty: Investing in women's work. American Planning Association. Journal of the American Planning Association 66(3): 229-242, 2000.

[21] Siwar, C. and T. Basri Abd. Micro-finance capacity assessment for poverty alleviation: Outreach, viability and sustainability. Humanomics 17(1/2): 116-133, 2001.

[22] Hussain, M. M., K. Maskooki. Implications of Grameen banking system in Europe: prospects and prosperity. European Business Review 13(1): 26-41, 2001.

[23] Menon, N. Interdependencies in Micro-Credit Group: Evidence From Repayment Data. The Journal of Developing Areas. 40(2): 111-132, 2007.

[24] Basher, M. A. Empowerment of Microcredit Participants and its Spillover effects: Evidence From The Grameen Bank of Bangladesh. The Journal of Developing Areas 40(2): 173-183, 2007.

[25] Sarumpaet, S. The Modified Grameen Bank: A Sustainable Finaning Scheme for Micro Enterprises in Indonesia. Journal of Asia Entrepreneurship and Sustainability, 2005.

[26] Narayana, N. Indonesia's MBK Ventura tops MIX 2009 ranking of 100 microfinance institutions. Microfinance News, 2010.

[27] Haryadi, A. Understanding and Developing Micro takaful in Indonesia. Paper presented at International Micro Insurance Summit 2010. Crowne Plaza Hotel, London, 2010. 